\title{
The Urgency of Gresik Wooven Sarong as Local Wisdom Research
}

\author{
${ }^{1}$ Wulandari Harjanti ${ }^{*},{ }^{2}$ Ujianto, ${ }^{3}$ Akhmad Riduwan \\ ${ }^{1}$ Student of Management Science Doctoral program STIESIA Surabaya \\ ${ }^{2}$ Lecturer of Doctoral Program in Economics, University of 17 August 1945 Surabaya \\ ${ }^{3}$ Lecturer of Doctoral Program of Management Science STIESIA Surabaya
}

\begin{abstract}
Local wisdom is seen as something that contains goodness for the lives of the people who embrace it. With the development of local industries, local excellence will become the potential for specific resources that are part of the scope of regional development planning. In one regional community in Gresik district, the community weaves traditionalist sarong and strongly holds local traditions which it considers as a legacy from their ancestors. From a tradition within a group / community comes the character in the group, this trait gives rise to local wisdom, namely; religious Islam, Mutual Cooperation and Panggungan (souvenirs) are inherent in the hospitality of the community in Gresik Regency which is pursued as a terminology in driving Small businesses in Gresik that continue to develop with the help of the Gresik district government
\end{abstract}

Keywords: mutual cooperation, local wisdom, Islamic religion, weaving

\section{Introduction}

From history to socio culture it can be said that woven sarong is an industry with complex environmental dynamics and the development of promising potential in the super millennial century. The success of a business is determined by hard work, even with a traditional system as long as it is well managed, then a business is able to welcome healthy competition, but does not change the culture of the community.

The phenomenon that the course of human history from the very primitive to the very modern developments today is never separated from its dependence on natural resources. This dependency has produced environmental dynamics in various models of natural resource development whose main purpose is to preserve them. The natural resource management model is very dependent on the characteristics of natural resources, regional characteristics, and socioeconomic characteristics of the people. In the seminar conducted by Irwansyah and Maya (2012), regional economic growth was basically influenced by the comparative advantage of one region, regional specifications and economic potential of the region. Changes to governance management by making regional autonomy the implementation (implementation) of the demands of globalization to empower regions by giving wider authority. Regional Autonomy in Indonesia began to be implemented in 2001 and the substance of the implementation of autonomy is to regulate and manage the regional households themselves, both the government, regional resources / potential, regional development.

The industry in Gresik is very lucrative for nomads from other regions to find decent work, such as the existence of PT. Semen Gresik; PT. Behaestex. The large number of migrants will not only increase the number of workers in Gresik, but they will also tighten the Gresik area. Population which is concentrated in the city area is also a problem for Gresik Regency, this is caused by the large number of industrial activities in the city area and it is not spread evenly throughout the Gresik region. "What is the strategy for developing woven sarong based on local wisdom in Gresik?

\section{Literature Review: Local Interest in Central Modernity}

Local cultural wisdom is local knowledge that has been so integrated with belief systems, norms, and culture, and is expressed in traditions and myths held for a long time. Innovation and local wisdom are often seen as conflicting. Innovation, as the forerunner or trigger for the onset of social change, is considered to represent the modern, dynamic and passionate side of society to achieve progress. Whereas local wisdom is 
often accused of being too traditional, static, and tends to contain the desire to maintain a state of being as it is.

This assumption is also reinforced by the opinion of most modernization theory figures that traditional culture, including local wisdom, is a sign of backwardness and a barrier in achieving socio-economic progress. An opinion that further strengthens the polarization between innovation and local wisdom. However, different opinions expressed by Michael R. Dove (in Suwarsono, 1994: 62-63). For Dove, traditional does not have to mean retarded. In his study of the interaction between Indonesia's national development policies with diverse cultures and local wisdom, Dove sees that traditional culture is very and always related to the process of economic, social, and political change of the people in the place where the traditional culture is attached. If this is the case, according to Dove, traditional culture will always experience dynamic changes, so that it does not hamper innovation towards progress.

Edith Penrose published a book entitled, The Theory of the Growth of the Firm which explained that the contribution of developing resource-based theory (RBV) included:

1. A set of productive resources that a company can control is different even in the same industry

2. Penrose adopts a broader definition for productive resources compared to the definition offered by Ricardian economics which only focuses on a few types of productive resources.

3. Penrose acknowledges that there are additional resources for the diversity of resources the company has, so they are considered productive resources.

And Barney (1999) states that the ability to be replicated or replicated from these resources depends on the extent to which these resources are protected by protection mechanisms. The advantage is tangible if the company has implemented a strategy of creating value or profit simultaneously and holistically compared to its competitors. Whereas sustainable competitive advantage is based more on optimizing the utilization of available resources and resources that can be controlled and none of the companies have the same strengths and weaknesses, so competence is an important differentiator.

Emphasizing the role of resources and capabilities as a basic source in an organization's strategy for profit has become an important focus in the 1990s and has been widely discussed in the strategic management literature. Emphasis on the role of organizational resources and capabilities as the basis of this strategy, due to factors such as the company's industrial environment which is increasingly unstable and uncertain experienced by the organization. Grant (2001) argues that the role of resources and capabilities of a company is the basis for a company's strategy. The focus on the utilization, management of resources and the dissemination of internal capabilities of the organization, is intended so that the organization can deal with uncertainty and dynamics of its environment so that an organization can survive and be able to achieve its goals.

According to Fuhl (2006) quoting from Barney (1995) suggested that looking inside for competitive advantage is the center of the slogan of resource-based view as well as questions in the form of why are firms different and how do firms achieve and sustain competitive advantage? This concept makes an organization's dependency to optimize the overall owned resources compared to competitors. The organization will be considered to have success and be able to maintain existence, if the organization is able to have unique resources that exceed those of competitors. According to Coo and Bontis (2002) quoting from Huizing and Bouman suggested that superior organizational performance depends on the ability of the organization to develop its unique resources and capabilities.

In local wisdom, a culture is a reflection of the actualization of an entrepreneur's business behavior, because the decisions taken by someone are influenced by cultural identity. Pragantha (1995: 33) states that companies with different cultural backgrounds have different business management behaviors. The elements of difference are found in the cultural style which characterizes specifically in management. This condition is determined by ethnicity, religious teachings, language diversity and geographical factors. This is in line with the statement of Waldinger et al, 1990 (Masurel et al., 2002) that some ethnic groups have cultural norms that define a number of understandings of economic behavior and expectations that are appropriate in the background of a job. 
Kreiser (2002) states that cultural attributes can have a strong impact on entrepreneurial formation and behavior, in addition, Knight's (1977) research shows that only countries with certain cultural tendencies will produce a strong entrepreneurial orientation and hence will experience more entrepreneurial activity and global competitiveness.

According to Wirakusumo (1997), entrepreneurship is derived from the translation of "Enterpreneurship", which can be interpreted as "the backbone of economy", namely the economic nerve center or as the "tailbone of economy", namely controlling the economy of a nation. The term entrepreneurship (entrepreneurship), was first used by Cantilon (1755) as a term for traders who buy goods in regions by setting prices for goods to sell, but at uncertain prices (Suryana, 2003)

Furthermore Suryana (2003) states that epistemologically, entrepreneurship is a value needed to start a business (start-up phase) or a process of doing a new (creative) and something different (innovative).

This research principally seeks to explain the local wisdom of how to woven sarong that is done with a nonmachine loom (ATBM) on the dynamics of the environment with the business potential in Gresik district that has survived to the present. In the framework of thinking, research is directed to describe local wisdom, by describing the expected local superiority in product strategies and marketing strategies, it is expected to create a competitive advantage that will affect the strategic factors that develop the weaving industry itself.

This research was conducted as a form of admiration for local wisdom in the Gresik area and the peculiarities of woven sarong that remained from non-machine looms (ATBM) despite intense competition from machine looms, sarong entrepreneurs were still able to continue but if not there is local wisdom from the local government in business development, to interfere with the price of cheap raw materials and help in the promotion and provision of new market shares and capital assistance with low interest, the researchers gradually worry that the craftsmen and entrepreneurs of Gresik typical weaving gloves may be will be a memorable history of the existence of a woven sarong from a loom not a Gresik machine.

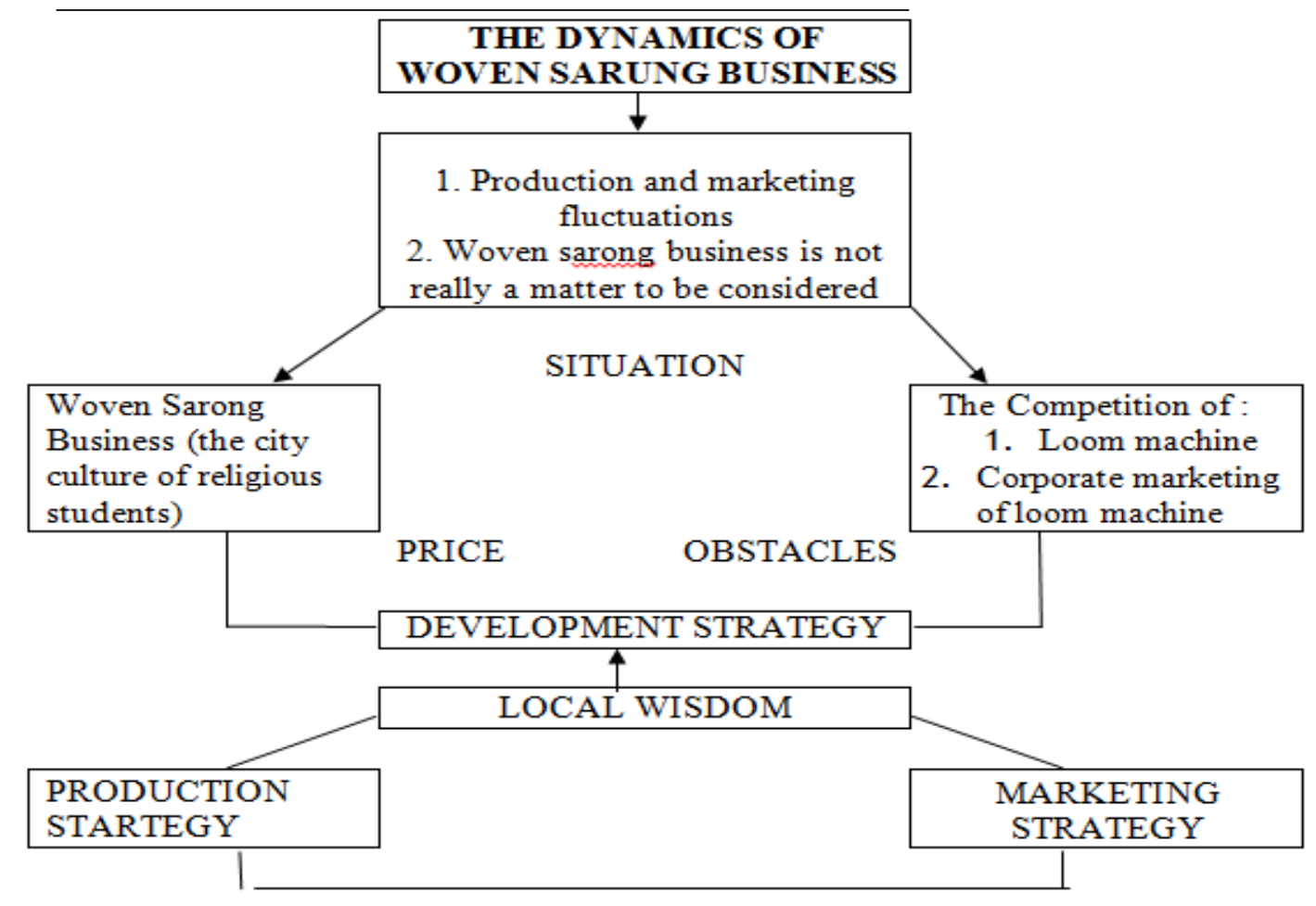

Figure 3.1 Research Thinking Framework

\section{Research Methods}

This research is a type of qualitative research, for several reasons. First, the phenomenon of local wisdom is seen as a whole (holistic) and not its parts, it is not possible to reduce the phenomenon of a complex process of local wisdom research, related to government, culture and community. Second, emphasizing the description (description) of natural (natural) or interpretation of the process of environmental dynamics in 
the learning of business potential with the context of meaning given by the craftsman to the experience they experienced. Third, research is done naturally, not making assumptions.

Various ways of collecting data for qualitative research continue to develop, but basically there are four basic ways to gather information, namely:

1. Observation, which is an interpretation of Karl Popper's theory, namely when entering the classroom with the intention of observing, it is better to leave the theories to justify a theory or refute. Observation is an act or process of taking information through observation media. Observations were made at the Cooperative allianz and the Industry and Trade Office of Gresik Regency to hold a meeting with the head of the office, then to the woven sarong entrepreneurs in two areas, Benjeng and Cerme, in order to obtain local wisdom of the sarong weaving on the condition of the businessman and the consisors of the discussion back from the meeting.

2. Interview is a meeting that is planned directly between the interviewer and the interviewee to give / receive certain information. According to Moleong (2011: 148) interviews are conversational activities with specific intentions carried out by both parties, namely the interviewer and the interviewee. Interviews are questions conducted verbally to people who are considered to be able to provide information or explanation of things that are deemed necessary. And in this study using standard and scheduled interviews, with three interviews; Phase 1 interview and Phase 2 interview lasts about 30 minutes to 2 hours and Stage 3 interviews (member check) about 60 minutes, and are willing to record their activities during the interview or during the study and give approval to publish the results of research .

3. Documents according collections originating from observational sources, notes on weaving research involving research participants will provide a framework for basic data, namely documents available at the office of the district policy maker in Gresik, located at Department of Industry and trade Gresik district where the weaving craftsmen and sarong shelter.

4. Triangulation is a data collection technique and data sources that already exist, the purpose of triangulation is not to find the truth about some phenomena.

\section{Findings of Local Life in Gresik in Sarung Weaving}

So that the findings of this study found a tradition of woven sarong community found 3 things that are economically growing and maintained in local wisdom Gresik namely;

a) Islamic Religious.

Religious value (diversity) is one of the various value classifications above. Religious values come from religion and are able to penetrate into the soul's intimacy. This inculcation of religious value is important in order to stabilize the work ethic and scientific ethos of the entire area of the sarong divination business. Worship is an Indonesian language that is derived from Arabic, namely from masdar 'abada which means worship. Whereas in term it means reverence for God, obeying His commands and avoiding His prohibitions. So worship is human obedience to God that is implemented in daily activities such as prayer, fasting, almsgiving, and so forth.

\section{b) Panggungan (souvenirs)}

Panggungan or The stage is a gift as an expression of gratitude from someone for the attention of others, or according to the city of Gresik that the grill is the same as a souvenir when visiting the event. In the form of objects, any objects according to the moment in Indonesian culture and Gresik's ancestors when visiting people who have a desire, the form of attention is realized by helping to provide celebration materials, which can be rice, bananas, energy and others. Or even more practical is help in the form of money. While gifts are absorbed from western culture. At present, assistance in the form of money has returned to entrenched, so for the expression of gratitude for those who have a desire will reciprocate by providing food or food ready to eat.

c) Gotong Royong (Mutual cooperation)

In the local wisdom of Gresik, mutual cooperation has strong conditions to help weaving MSMEs, with the obstacles that arise from the reduction of young workers, mutual assistance is needed in terms of building together for mutual prosperity and can support the family. 
So that in this study, several variables and scores from the PUP district government of Gresik are described as follows:

Table 4.1 Variables and Scores

Determination of Priority Featured Products (PUP)

\begin{tabular}{|c|c|c|}
\hline No. & Variables & Score \\
\hline 1 & $\begin{array}{l}\text { Characteristic / The level of } \\
\text { local uniqueness }\end{array}$ & $\begin{array}{l}0 \text {, if not unique (can be found anywhere). } \\
1 \text {, if it is quite typical (can be found in many other regions, but } \\
\text { there are special characteristics of products that are typical of } \\
\text { Gresik) } \\
2 \text {, if Gresik is unique (found in Gresik, although there are in other } \\
\text { regions, although not much, the product has a character that } \\
\text { distinguishes it from the same product). }\end{array}$ \\
\hline 2 & $\begin{array}{l}\text { The origin of production / } \\
\text { industrial raw materials }\end{array}$ & $\begin{array}{l}0, \text { if all come from outside Gresik. } \\
1 \text {, if the majority (> 50\%) comes from outside Gresik. } \\
2 \text {, if the majority (> 50\%) comes from Gresik. } \\
3 \text {, if all }(100 \%) \text { comes from Gresik. }\end{array}$ \\
\hline 3 & $\begin{array}{l}\text { The origin of labor in the } \\
\text { production process }\end{array}$ & $\begin{array}{l}0, \text { if all workers come from outside Gresik. } \\
1 \text {, if the majority (> } 50 \%) \text { comes from outside Gresik. } \\
2 \text {, if the majority (> 50\%) comes from Gresik. } \\
3 \text {, if all }(100 \%) \text { comes from Gresik (Local). }\end{array}$ \\
\hline 4 & $\begin{array}{l}\text { The process of inheriting the } \\
\text { skills / abilities of Human } \\
\text { Resources in the production } \\
\text { process }\end{array}$ & $\begin{array}{l}\text { 0, skills are only possessed by workers who currently do not have } \\
\text { efforts to regenerate skills in the next generation of workers. } \\
1 \text {, the skills are only possessed by workers who currently have } \\
\text { efforts to regenerate skills in the next generation of workers, but } \\
\text { are classy. } \\
\text { 2, everyone can continue easily / unlimited regeneration. }\end{array}$ \\
\hline 5 & technology & $\begin{array}{l}0 \text {, there has never / never been technological innovation in the } \\
\text { production process. } \\
1 \text {, there are potential possibilities / new innovations in production. } \\
2 \text {, using new technologies and / or innovations in production } \\
\text { processes. }\end{array}$ \\
\hline 6 & $\begin{array}{l}\text { Kombinasi SDM dan kapital } \\
\text { dalam proses produksi }\end{array}$ & $\begin{array}{l}0, \text { jika padat karya atau padat modal } \\
1 \text {, jika relatif seimbang anatar keduanya (mampu menyerap tenaga } \\
\text { kerja sekaligus tetap bisa memanfaatkan teknologi). }\end{array}$ \\
\hline 7 & $\begin{array}{l}\text { The existence and role of } \\
\text { institutions }\end{array}$ & $\begin{array}{l}0 \text {, if not / there is no community / cooperative } \square \text { institutional } \\
\text { overshadow. } \\
\text { 1, if there are already institutions that overshadow, but are still } \\
\text { passive. } \\
2 \text {, if there are institutions that overshadow and are active. }\end{array}$ \\
\hline
\end{tabular}




\begin{tabular}{|l|l|l|}
\hline 8 & $\begin{array}{l}\text { Market availability } \\
\text { (marketing target) }\end{array}$ & $\begin{array}{l}0, \text { do not have a market yet. } \\
1, \text { already has a market but is limited. } \\
2, \text { already have a wide market. }\end{array}$ \\
\hline 9 & Product packaging & $\begin{array}{l}0, \text { not packed yet. } \\
1, \text { packed, but not yet registered (do not yet have a registration } \\
\text { number from the Ministry of Health <BPOM or Department of } \\
\text { Industry and Trade) } \\
2, \text { packed and registered. }\end{array}$ \\
\hline 10 & $\begin{array}{l}\text { Market segment } \\
\text { a, only certain groups. } \\
11, \text { certain but broader group. } \\
2, \text { all groups. }\end{array}$ \\
\hline 12 & $\begin{array}{l}\text { Number of upstream related } \\
\text { sectors }\end{array}$ & $\begin{array}{l}\text { Number } \\
\text { downstream sectors } \\
\text { primary products (agricultural products). In accordance with the } \\
\text { definition } \square \text { the scope of the manufacturing industry, the minimum } \\
\text { industrial sector will have an upstream sector, namely the } \\
\text { agricultural sector. } \\
\ldots, \text { fill in the number of how many upstream sectors. }\end{array}$ \\
\hline
\end{tabular}

\section{Source: Cooperative allianz Service, 2019}

The ATBM industry has forward and backward links. Backward linkages are related to the fulfillment of raw materials and support in making weaving crafts, while future links with marketing and further processing of weaving crafts. In addition to these links, the weaving craft industry also has links with other fashion derivative industries, as well as tourism. The linkage and / or cooperation of the non-machine loom (ATBM) weaving craft industry is not only within the area of Gresik district, but also outside Gresik Regency.

\section{Backward Linkage}

The non-machine loom (ATBM) industrial inputs include raw materials, equipment, labor and capital. The chain of weaving production activities begins with the procurement of raw materials, namely yarn. The type of yarn used depends on the product you want to produce. The yarn raw material can be bought easily in the city of Surabaya. For silk yarn that has high quality, entrepreneurs use imported materials from China, Hong Kong and Taiwan.

These materials are purchased with a frequency of once or twice each month to save on transportation costs. During this time the availability of raw materials (both imported and local) in the market is quite a lot to meet the demands of the craftsmen, so that whenever and whatever amount is needed, craftsmen can get it immediately and never have trouble getting it and never run out.

The most important equipment to make weaving is Non-Machine Weaving Equipment the non-machine loom (ATBM) itself. This ATBM unit is provided by a loom manufacturer located in the city of Gresik. The vertical activity relationship is dominated by the linkages in the order of production goods in accordance with the production chain. The interrelation of vertical activities, both between raw material suppliers and entrepreneurs as well as entrepreneurs and suppliers, shows a great dependency between the entrepreneurs 
and the two business actors. This is indicated by the large number of production flows, the interrelationship in the aspects of business interrelation, the certainty of raw material inventory and production profits. In addition, there is also a connection with entrepreneurs of non-machine loom (ATBM) equipment and tools. More clearly about this is presented as in the following table:

\section{Forms of Backward Linkages}

\section{In the Weaving Industry Cluster}

\begin{tabular}{|c|c|c|c|}
\hline $\begin{array}{l}\text { Type of } \\
\text { Relationship }\end{array}$ & $\begin{array}{l}\text { Form } \\
\text { Relationship }\end{array}$ & $\begin{array}{l}\text { Reasons or Factors to be } \\
\text { considered }\end{array}$ & The benefits \\
\hline \multirow[t]{4}{*}{$\begin{array}{l}\text { The linkages with } \\
\text { raw material } \\
\text { suppliers }\end{array}$} & $\begin{array}{l}\text { Business linkages or } \\
\text { raw material orders }\end{array}$ & $\begin{array}{l}\text { 1. Transportation costs' } \\
\text { efficiency } \\
\text { 2. Limited capital }\end{array}$ & $\begin{array}{l}\text { 1. Production cost's } \\
\text { efficiency } \\
\text { 2. Production costs' } \\
\text { minimization of }\end{array}$ \\
\hline & $\begin{array}{l}\text { The raw material } \\
\text { inventory's certainty }\end{array}$ & $\begin{array}{l}\text { 1. Streamlining production } \\
\text { 2. Minimize risk } \\
\text { 3. The employers' } \\
\text { commitment to fulfill } \\
\text { orders on time in the } \\
\text { quantity and quality of } \\
\text { orders }\end{array}$ & $\begin{array}{l}\text { The company demand's } \\
\text { accuracy does not run out } \\
\text { of inventory, so that } \\
\text { customers are satisfied }\end{array}$ \\
\hline & $\begin{array}{l}\text { Transportation's } \\
\text { Cost efficiency of of } \\
\text { raw materials }\end{array}$ & $\begin{array}{l}\text { 1. Limited capital } \\
\text { 2. Minimizing total } \\
\text { production costs through } \\
\text { savings in transportation } \\
\text { costs }\end{array}$ & $\begin{array}{l}\text { production costs' } \\
\text { efficiency }\end{array}$ \\
\hline & $\begin{array}{l}\text { Production } \\
\text { advantages }\end{array}$ & $\begin{array}{l}\text { 1. Lower price } \\
\text { 2. Production's continuity is } \\
\text { maintained } \\
\text { 3. Product quantity and } \\
\text { quality are maintained by } \\
\text { leading to improvement }\end{array}$ & $\begin{array}{l}\text { 1. Increase profits } \\
\text { 2. Quantity or product } \\
\text { quality increases }\end{array}$ \\
\hline $\begin{array}{l}\text { The linkages } \\
\text { suppliers } \\
\text { helpers }\end{array}$ & $\begin{array}{l}\text { Business linkages or } \\
\text { orders for supporting } \\
\text { materials }\end{array}$ & $\begin{array}{l}\text { 1. The need for weaving } \\
\text { production in increasing } \\
\text { competitiveness } \\
\text { 2. Selection of quality } \\
\text { auxiliary materials } \\
\text { 3. Helping materials are } \\
\text { needed in coloring and } \\
\text { motives } \\
\text { 4. Companies must be able } \\
\text { to read changes in tastes, } \\
\text { especially colors and } \\
\text { motifs }\end{array}$ & $\begin{array}{l}\text { 1. Expansion of } \\
\text { production } \\
\text { 2. Product innovation } \\
\text { 3. Customer loyalty }\end{array}$ \\
\hline
\end{tabular}




\begin{tabular}{|c|c|c|c|}
\hline & $\begin{array}{l}\text { Production } \\
\text { advantages }\end{array}$ & $\begin{array}{l}\text { 1. Product innovation } \\
\text { 2. Variation in product } \\
\text { motives design } \\
\text { 3. Product style adjustments } \\
\text { according to market } \\
\text { tastes } \\
\text { 4. Products are more } \\
\text { competitive }\end{array}$ & $\begin{array}{l}\text { 1. Product quality } \\
\text { increases } \\
\text { 2. Products are more } \\
\text { acceptable to the } \\
\text { market } \\
\text { 3. Profits increase }\end{array}$ \\
\hline $\begin{array}{l}\text { Non-machine loom } \\
\text { (ATBM) business } \\
\text { and equipment }\end{array}$ & $\begin{array}{l}\text { Provision } \\
\text { production } \\
\text { equipment }\end{array}$ & $\begin{array}{l}\text { 1. Streamlining production } \\
\text { 2. The need for weaving } \\
\text { production in increasing } \\
\text { competitiveness }\end{array}$ & $\begin{array}{l}\text { Quantity and product } \\
\text { quality increases }\end{array}$ \\
\hline
\end{tabular}

\section{Source: Cooperative allianz Service}

\section{Forward Linkage}

The non-machine loom (ATBM) weaving craft industry produces sarong that are ready to be marketed. So for the future linkages, business actors or IKB weaving ATBM cooperates with entrepreneurs and distributors and even directly deals with direct consumers (local markets). For overseas marketing, exporters are associated with large entrepreneurs. For inter-regional markets, business actors engage with distributors to distribute their products, whereas for local markets, players can market directly even without distributors.

The interrelationship of future activities is only dominated by the relationship between large entrepreneurs and buyers. The advantage of this relationship is product promotion. While the weakness is in the designs of weaving motifs that depend on the demand of the buyer and the bargaining position is relatively weak. In addition there is a payment risk borne by the craftsman because the payment system requires the craftsman to send goods in advance, so the craftsman must have sufficient capital to finance production. Whereas the linkage between sub-contracts of small-scale craftsmen and large-scale craftsmen is only limited to marketing, where small-scale craftsmen place their products on large-scale craftsmen who on average already have their own showroom outlets.

The weaving industry in Gresik Regency has been formed in an industrial cluster. The large non-machine loom (ATBM) weaving cluster in Cerme, Benjeng and Gresik sub-districts is clearer about the future linkages presented in the table below but the linkages built by industries in these clusters are still relatively weak, due to the limitations of business operators, especially small-scale craftsmen-contract in building a marketing network and still depends on large craftsmen, this weakness is greatly influenced by the limited capital owned by small industries.

Table of Forms of Future Linkages in the Weaving Industry Cluster

\begin{tabular}{|l|l|l|l|}
\hline Type of Relationship & $\begin{array}{l}\text { Form of } \\
\text { Relationship }\end{array}$ & $\begin{array}{l}\text { Reasons or Factors to be } \\
\text { considered }\end{array}$ & The benefits \\
\hline $\begin{array}{l}\text { The linkages of large } \\
\text { craftsmen/ exporters - } \\
\text { small craftsmen }\end{array}$ & Business linkages & $\begin{array}{l}\text { Established craftsmen } \\
\text { usually have outlets or } \\
\text { showrooms so that marketing } \\
\text { can be wider }\end{array}$ & $\begin{array}{l}\text { Expanding continuity of supply } \\
\text { carket }\end{array}$ \\
\hline
\end{tabular}




\begin{tabular}{|c|c|c|c|}
\hline \multirow[t]{2}{*}{ Linkages - exporters } & $\begin{array}{l}\text { Business linkages } \\
\text { or production } \\
\text { orders }\end{array}$ & $\begin{array}{l}\text { 1. Market certainty } \\
\text { 2. Market expansion } \\
\text { 3. Sustainability } \\
\text { production } \\
\text { 4. Big profits }\end{array}$ & $\begin{array}{l}\text { 1. There is a clear target } \\
\text { market } \\
\text { 2. Each craftsman has } \\
\text { his own buyer so as } \\
\text { to minimize unfair } \\
\text { competition }\end{array}$ \\
\hline & $\begin{array}{l}\text { Promotion of } \\
\text { relationship }\end{array}$ & $\begin{array}{l}\text { 1. Promotion activities and } \\
\text { exhibitions are conducted } \\
\text { regularly } \\
\text { 2. Promotion is able to } \\
\text { expand the market }\end{array}$ & $\begin{array}{l}\text { 1. Expand the market } \\
\text { 2. Production volume } \\
\text { increases } \\
\text { 3. Business continuity is } \\
\text { guaranteed }\end{array}$ \\
\hline $\begin{array}{lcc}\text { Linkages } & \text { of } & \text { local } \\
\text { exporters } & - & \text { local } \\
\text { traders } & & \end{array}$ & $\begin{array}{l}\text { Business linkages } \\
\text { or production } \\
\text { orders }\end{array}$ & $\begin{array}{l}\text { 1. Market certainty } \\
\text { 2. Production's } \\
\text { sustainability } \\
\text { 3. Acceptance's stability }\end{array}$ & $\begin{array}{l}\text { 1. The profit is } \\
\text { relatively stable } \\
\text { 2. The company still } \\
\text { exists }\end{array}$ \\
\hline
\end{tabular}

\section{Source: results of secondary data from the Department of Cooperatives}

In the context of this research, the desire to accommodate three local wisdom entities, namely Islamic religion, Gotong Royong (mutual cooperation) and Panggungan, is an inseparable part of the life of the woven sarong community, seen in the concrete reality that is presented, especially in the production of woven sarong, it is clearly seen that the three local wisdoms are very much well appreciated by all components of the community in the environment. At present they (home industry informants) do not only prioritize and make themselves as priority, so that others seem to be seen as unimportant, in local wisdom the three view it as very important to practice so that there is a strong desire to strengthen existing clusters to increase marketing, will said in this study is a clash of local wisdom that has been entrenched, so that the development of woven sarong with local wisdom further strengthens the home industry in implementing its production and marketing.

The potential development of a woven sarong business called home industry is carried out and owned by the perpetrators of economic activities based at home is the family itself by inviting people around its area as employees. Although on a small scale, this economic activity indirectly opens up employment opportunities for relatives or neighbors. That way, this small company helps the government program in reducing unemployment; automatically the number of poor people will gradually decline. This is a potential development that is owned by woven sarong

Business potential can be used by sellers and entrepreneurs who are agents and distributors with the following considerations:

1. Sarong the most important means of worship for male Muslims is because the sarong is one of the ways of worship itself, besides the prayer mat. Not using gloves and prayer rugs is also okay, but it would be nice if you use it as an etiquette in worship.

2. Always looking for souvenirs, for relatives to use later on Eid. To welcome the Eid=Fitr feast of course everyone wants to look new as a sign of our gratitude to The Almighty of Allah. Likewise for people who want to go home, sarong and prayer rugs become souvenir items in addition to clothing and food for their loved ones.

3. A promising profit because of the potential business of selling sarong and prayer rugs should not be asked again, especially if entering the month of Ramadan and the pilgrimage, then the profit that can

be increased several times. By order sarong and prayer rugs in the month of Ramadan will be very much in the order well in advance of the Eid al-Fitr. 
4. Sarong is very easy to market because marketing of sarong and prayer rugs is one that is always sought after by the general public. Especially if you have good quality goods, then the customer will come by itself.

5. The capital is very affordable, especially if you understand the art and color offered on the sarong, you can quickly come directly to the factory or home industry to order sarong and prayer rugs with the desired brand.

The potential of woven sarong business is deemed underdeveloped because of the many young workers who prefer to work in factories rather than opening their own businesses due to lack of awareness and lack of confidence to open their own businesses. Most people tend to have the mindset to live comfortably as employees, and forget that there is potential developed and generated in the woven sarong business.

\section{Conclusion}

Seeing the phenomena that occur in Gresik society where Gresik culture is strongly influenced by the values of Islamic teachings that are implemented in daily life. Likewise in activities to make a living. As the dynamics and development of business potential with high and noble local wisdom, that is, Islamic religion, Gotong Royong (mutual cooperation) and Panggungan with development strategies based on production strategies and marketing strategies are able to answer technological developments. That local wisdom can still grow and develop small businesses woven sarong in the midst of existing modernity.

\section{References}

[1.] Anderson, K. and Kerr. C. 2002. Customer Relationship Management. McGraw-Hill Companies, Inc.

[2.] Barney, J.B. (1991) Firms Resources and Sustained Competitive Advantage.Journal of Management 17.pp.99-120.

[3.] Barney J. B. 1995. Looking inside for competitive advantage; Academy of Management Executive, Vol. 9 No. 4: (49-61)

[4.] Barney, J. 1991. Firm Resoures and Sustained Competitive Advantage. Journal of Management 17 (1): $99-120$

[5.] Emory, C.W. and Cooper, D.R. 1995. Business Research Methods. Fifth Edition. USA

[6.] Grant, R. 1991. The Resource-based Theory of Competitive Advantage: Implications for Strategy Formulation. California Management Review. (spring) 112-135

[7.] Irwansyah, dan Maya. S. D. 2012. Local Wisdom Laksado Community Empowerment Based on Local Wisdom. National Seminar on Eco - Entrepreneurship. Semarang State University. Semarang.

[8.] Kreiser. P. M. L.D. Marino and K.M. Weaver. 2002. Assessing the Psychometric Properties of Entrepreneurial Orientation Scale: A Multi - Country Analysis. Journal of Enterpreneurship Theory and Practice. Vol. 26. Iss. 4. P. $71-03$

[9.] Masurel, E.; N. Peter; T. Murat, and V. Gabriella. 2002. Motivation and Performance Condition for Ethnic Entrepreneurship, Journal of Growth and Change, Vol. 33, Iss. 22, p. $238-260$

[10.] Moleong, Lexy J. 2004. Metodologi Penelitian Kualitatif, Edisi Revisi, PT. Remaja Rosdakarya: Bandung

[11.] Moleong, 2011. Qualitative Research Methods: A New Paradigm of Communication and Other Social Sciences, Remaja Rosdakarya Bandung.

[12.] Pragantha, Revi. 1995. Memperkuat Budaya Perusahaan, Majalah Manajemen dan Usahawan No.4 Tahun XXIV, April. Jakarta

[13.] Suwarsono. 1994. Sosial Change and development, LP3S

[14.] Suwarsono. 1994. Project Feasibility Study. Third Edition. AMP YKPN Publisher and Printing Unit, Yogyakarta.

[15.] Suryana. 2000. Development Economics: Problems and Approaches. First edition. Salemba Empat. Jakarta.

[16.] Suryana. 2003. Entrepreneurship, Practical Guidelines, Tips and Processes for Success.PT.Salemba Empat. Jakarta.

[17.] Wirakusumo, S. 1997. The Role of Higher Education in Creating Resilient Entrepreneurs. Seminar Paper: Jatinangor: PIBI-IKOPIN and FNSt. 